\title{
The Professor Looks at the Card Catalog
}

Mr. Kerr, librarian of Claremont Colleges, read this paper before the Los Angeles Regional Group of Catalogers, Pasadena, April 14, 1942, and before the Southern California Conference of College and University Librarians, Pasadena, May 4, 1942.

A a college librarian, I am trying $\mathrm{A}_{\text {to represent our friend, the college }}$ professor, who in himself and in his influence is probably the largest user of the library card catalog. Indirectly I am speaking for his students.

I thought I knew the mind of the professor, but to be sure of my ground I sent a questionnaire to some eighty-two teachers, deans, and presidents in nine institutions of southern California. I chose names from all departments of instruction and included younger as well as older teachers. Forty-seven replies came back: three presidents, six deans, thirty-five professors, and three librarians. The three librarians should be explained: one of the presidents and one of the deans promptly referred the questionnaire to his librarian. What does a college have a librarian for? One of the most suggestive answers came from Andrew D. Osborn, of the Harvard library, who is quoted later on. One of the presidents sent this reply: "I am not competent to speak on the desirability of this or that card. I am one of those softies who, when he wants a book, has people who are wise and who bring him the book."

I asked five main questions, breaking each into subtopics in order to obtain details of opinion. The five main points were:

I. For what do you usually consult your library card catalog?

2. Do you consult the subject cards?

3. Do you know how much it costs to catalog a book?

4. What do you tell your students about their use of the library catalog?

5. In short, if you were doing it, how would you catalog your college (or university) library?

I am trying not to take sides in the moot points, but you will judge my point of view from some of the questions I submitted.

\section{Uses of the Card Catalog}

Obviously, a bull's-eye was scored by the first query: "Do you usually consult your library card catalog in order to ascertain whether your library has a certain book and, if so, its call number?" Forty-six replied enthusiastically "yes." Possibly the very unanimity should have a meaning for us. Query: "To obtain full name of author and when he lived?" Sixteen say "yes," five say "no," four say "occasionally" or "seldom." Six indicate that dates of birth and death do not signify. Query: 
"To obtain exact title of book?" This drew twenty-four affirmative answers, two negative, and seven qualified answers. One professorial friend remarks about author's full name, dates, and exact title of book: "I rarely look in catalog for these two, but they should be suppliedin case." Query: "To verify place and publication date of book?" "Yes," eighteen. "No," two. "Seldom" or other qualifications, five. One answer fancies especially the place of publication. Query: "To learn whether the book was published in a certain series?" The answers to this grieve me, because I dote on series entries. Only three say "yes," three are doubtful, and ten say positively "no." Query: "To obtain full description of book: number of pages, maps, illustrations, size (in centimeters or inches?-I put that in wickedly, thinking I would get a rise from more than one professor-but only one indicated preference for inches!), table of contents, edition?" This "bibliographical embroidery," as Mr. Bowker called it, is very dear to me, but only six of my friends value it, one is doubtful, one wants number of pages only, two value table of contents, while ten coldly say "no." I can't believe they all mean it. I feel a little better about my next query: "Do you value notes (such as 'first edition'-only two value that-or 'at head of title') or notation of 'bibliography, p. . . .?"' Fourteen are on my side with "yes" votes, nine say "no," and five ask specially for notation of bibliography. Query: "Do you like to know who published the book?" Twenty-four say "yes," seven answer "occasionally" or "seldom," four don't care. I might have known the answer to my query: "Do you usually look for a book by its author? Or by its title?" Forty-three say "by author," ten "by title," one neither.
Now it will be noted that, statistically speaking, from these answers, the average professor uses the card catalog: I. To ascertain whether the library has a certain book and where it is shelved; only a minority wants full name and dates of author. 2. Place and date of publication get in only by a narrow squeak. Publisher is wanted. These would give us on a card only author, title, place, date, and publisher. Subject cards are taken up in the next series of questions.

But some of the answers do not arrange themselves by yes or no. They need to be quoted: One well-known professor of English says his use of the catalog "depends upon my forgettery." Another equally well-known professor of English confesses: "I usually get place and publication date, series note, bibliographical description, and notes (when I need them) from the sources; but the catalog should supply the information-in case. In all such matters I tend to make the catalog an insurance policy-my recourse if other things fail." A college president asks for book evaluation in the catalog, thus: "A consensus of authoritative value judgments would be helpful to students who have limited knowledge of bibliography. They tend to 'believe' printed matter and need guidance of a critical sort." A professor of history says the "entry of series under easy cross references is a problem, especially hard-to-find large series, such as California state papers, inedited documents, etc." A professor of public administration bluntly remarks: "I use the catalog only to secure the book. Prefer to get other data from the book itself." What if the book is out, friend? But your remark reminds me of the quip attributed to Archibald Cary Coolidge, of Harvard: "Why should the card catalog 
describe the book? The library has it."

A wise over-all point of view is Dr. Osborn's summary of the uses of the card catalog: "The official uses are for book selection, order work, cataloging, interlibrary loan, etc. For readers' purposes, the use by students is lessened because of reserved reading, the browsing room, the new book shelves, the house (dormitory) libraries, etc. Faculty and research workers have access to stacks, and main use of the catalog is for locating known books."

\section{Subject Cards}

The query, "Do you consult the subject cards?" brought twenty-one affirmative answers, ten negatives, and three qualified. In passing, it will be noted that many of these queries are not answered by all our professorial friends: in this case only twenty-one of forty-seven are definite in their use of subject cards; ten do not use them, three say "rarely" or "seldom," and thirteen do not. answer-why? The next query was: "Do you find it easy to hit upon the subjects used for the books in which you are interested?" Surprisingly, fifteen say "yes," fourteen say "no," and six answer "not always," "varies," "seldom," etc. Similarly, the query: "Do you find the subjects are up to date?" is answered affirmatively by thirteen, negatively by ten, and qualified by three. I would call this a vote of lack of confidence: thirteen to thirteen, with twenty-one not voting. Couple that with the next query: "Do you use your own bibliographies rather than the library subject catalog?" Affirmative answers are thirty-seven, while only seven report preference for the subject catalog.

The growing academic preference for subject bibliographies is nicely illustrated by a comparison of the first (1929) and second ( 1942 ) editions of a standard work in social studies: George A. Lundberg. Social Research. N.Y., Longmans. Ed. I, 1929. Ed. 2, 1942. The "selected references" in the first edition occupy forty-six pages (325-70). They are replaced in the second edition by "suggestions for further study" (critical annotations) at the end of each of the twelve chapters, usually a page or less, plus a "bibliography of bibliographies" (two pages). Moreover the author remarks in his introductory chapter:

For the general bibliography and appendices of the first edition I have substituted at the end of each chapter specific suggestions for further study of the subject under consideration. The enormous increase during the past decade makes it necessary for the student in the future to rely on annotated bibliographies indicating which studies are likely to contain material relevant to a particular inquiry. On the subject of attitude research alone, for example, there appeared in periodicals in English, during the years 1937-39 inclusive, some two hundred titles, not counting relatively inaccessible theses and papers and excluding all studies having no bearing on methodology. Annotated bibliographies for the field have, fortunately, become increasingly available, enabling students to go more directly to the relevant sources. A bibliography of such bibliographies, aggregating many thousands of titles, is appended to the present volume.

Again, some of the answers on subject cards must be quoted to get at their meat: A professor of psychology says subjects are not up to date, for "some antiquarian in Library of Congress must choose them." A professor of economics says, "My approach is through subjects more frequently than persons or titles." Similarly, a dean of education reports: "More frequently than any other use, I consult the catalog to find what we have concerning a subject or field. That is, my needs are more often than not bibliographical." One answer 
declares, "Subject cards should be set up even though the subjects at times only approximate student interests." A professor of English says it this way: "It seems to me that subject cataloging has been less helpfully done than any other kind. So often in past years did I fail to get relevant information and guidance speedily that I tend to ignore this side of the catalog except in a real pinch. Then I expect to make a job of it." A librarian replies, "For our particular library I favor more analytics for parts of books and fewer general indefinite headings. More cross references, especially from compound names." A historian says present subject headings are not up to date: "They served in the days of economic determinism and political emphasis. They are entirely inadequate for social, intellectual, and religious aspects, which are now equally important."

I conclude that we have enough source material in these answers for several headaches and for a full-scale investigation of subject cataloging.

\section{Cost of Cataloging}

I thought we might get some help on the age-long question of cataloging costs. Innocently, I asked: "Do you know how much it costs to catalog a book?" Four answer simply, "yes"-but do not tell me how much. Twenty-one answer "no." One says, "Not exactly." "Am not concerned." One says, "Often as much as the book costs." One says, "twenty-five to fifty cents." Three say, "fifty cents or mrre." Two say "seventy-five cents." One says, "About fifty cents to one dollar, I believe." Two say "one dollar." Notice that only ten of thirty-seven answers give any figure. Dr. Osborn says Harvard costs are gross $\$$ I.50, actual \$I.00, less valuable books fifty-two cents. The query, "How much do you think your institution is justified in spending for cataloging?" brought an array of suggestions. Seven say, "No more than necessary." Two say, "Not over fifty cents." Three say, "More than at present." One says, "Fewer books well cataloged." One says, "Enough to avoid making the library a cemetery." One says, "Ask the librarians." Three say cataloging is indispensable, whatever the cost. Eight are frankly puzzled to answer. Evidently, they want a catalog. I next asked, "Does your library catalog become obsolescent?" Four reply "yes," eleven "no," six say "yes, in spots," or "somewhat." When I asked, "Is the obsolescence of the catalog or of the books?" nine said of the catalog, while seventeen put the blame on the books.

My last query under cataloging costs was poorly phrased. I asked; "If ten college and university libraries in southern California each buy Davies, Mission to Moscow, do you think each library should do its own cataloging for it?" In the first place, several of our professorial friends do not think any library should buy that book! But I had in mind centralized or regional cataloging, not simply the use of L.C. printed cards, which most of the answers urged. Because the question was not clear, I think the answers do not signify much. Nine answer "yes," probably meaning by the use of L.C. cards; while sixteen say "no," probably meaning that L.C. cards should be used. Of course, they assume that when you have the printed card all the cataloging is done. One answer is typical of several which show that to many cataloging and classification are the same thing: "If cataloging is proving too expensive why not use classifications as given on Library of Congress 
cards since 1936 approximately?" Another answer shows some analysis has been made: "In the long run, I favor the efficiency of the local unit, whatever it is." And someone else asks, "Does L.C. really pay in a small library?" Several suggest printing of cards by publishers.

Three of the answers seem to catch my idea. One says, "Not if a central cataloging office could be arranged." Another says, "Not if a unified system would be cheaper and not much less expeditious." Still another says "each library should no more do its own cataloging than each university should print its own books."

I venture to put a surmise and a problem in arithmetic before you: If there are one hundred libraries in southern California each buying the same one hundred books annually, that is ten thousand volumes to be cataloged, either with or without L.C. cards. If each library spends fifty cents per volume for labor cost of cataloging, that is five thousand dollars for cataloging the same one hundred books. If we had a regional cataloging bureau, how much would it cost to deliver one hundred sets of cards ready to file, with call numbers, subject headings, added entries, and all? Would you use such cards if they cost you twenty-five or thirty cents (that is a pure guess by me) instead of your present cataloging cost? Or are we all following that will-o'-the-wisp, that the cataloging of an additional one hundred books does not really cost us anything?

\section{What Are Students Told?}

The next query was, "What do you tell your students about their use of the library catalog?" Eleven frankly answer, "Nothing." (I was surprised at that.) How- ever, one answer is: "I try to encourage all possible use of the catalog, from all possible angles, such as subject references, accuracy in listing, preparation of bibliographies, etc." Another answers suggestively: "I tell them to work through subjects, bibliographies, other works of men thus discovered, other related aspects of subject, etc. I differentiate public document, journal, and periodical material." How much more helpful are either of those, than this: "I tell them mostly that they should look books up by author and that the subject catalog is likely to be treacherous and cannot be really satisfactory," or this: "I tell them that they can't find much by the catalog."

Query: "In your opinion, for what does the average student use the catalog?" Of course, there are the expected answers: develop bibliographies, check references, expand material, etc. One doubting Thomas says the average student's use of the catalog is "superficial hunting of something to cram on." Another says, "I fancy students often try (and usually unsuccessfully) to use the subject index." Another says the same: "The average student looks up subjects in the subject catalog. $\mathrm{He}$ is often unsuccessful even though the books are in the library." Not so gloomy is this: "The student uses the catalog as a substitute for getting information from the staff; also to make out bibliographies for term papers (usually without discrimination)." Another opines that students "use the catalog to find books but even more to look up subjects. They should use bibliographies, but they won't." And finally here is this one: "The student uses the catalog to see whether the book is in the library, to get call number. Some use the subject index, but too much guessing is 
involved in trying to discover under what subject a book will be catalogued."

\section{How Would You Catalog Your Li. brary?}

Hoping to get some come-backs, I asked, "In short, if you were doing it, how would you catalog your college (or university) library?" I got the come-backs. First, there were eight who said the present method is O.K. Two said, "L.C. exclusively," one said, "Abolish Dewey "and use L.C.," another, "Our old D.C. catalog was very satisfactory." (You see, cataloging and classification are synonymous.) Other answers are: "Separate author and subject cards. ...." "Much more emphasis on subject catalog. ..." "Generous subject entries, simple entry. ..." "By title and author...." "Completely. ..." "A special subject catalog. ..." "By major schools and departments. ..." "Get publisher to furnish cards."

Several are sure in a different way: "I wouldn't. . .." "Nothing under heaven could induce me. . . " "Would refer it to Mr. Kerr. . . ." "I'd commit suicide. ..." "Heavens, no! . .." "This is an easy question!"

Some of the more definite suggestions are :

More breakdown of general subjects, with classifications more nearly in accordance with ends being served by curriculum and research.

I'd leave it to those who are trained to know how best to do it (known as passing the buck)! Catalogs seem to me marvelous in their information and arrangement and cross cataloging.

I don't see it as a problem, for our people are doing it very well for my purposes.

Use L.C. cards as we do but put books into circulation more rapidly by use of tem- porary slip in the catalog. Use more headings in the catalog, with duplicate cards in each good place.

I wouldn't try: This is a matter for library experts. They would know how best to make the library available as an important teaching tool and keep students interested in the library.

Make generous topical filings. Eliminate all information except name, title, publisher, edition, and subject.

In addition to the present general catalog, I would have brief catalogs of books desired according to courses and I would have these books grouped together on shelves accessible to students.

By subjects and fields, but the greatest shortcoming of the present system is the placement of books [classification] by the ordinary meaning of title rather than by its content. This is particularly serious in psychology.

This is a technical question and the layman and the mere user of a library is out of place to speak with any authority. I believe, however, that I would not have $m y$ catalog differ from the established practice, since we ought to be at home in any library after we have learned the setup of one. Doing otherwise would be like changing the alphabetic order of a dictionary-chaos would result.

About as now (Library of Congress system, modified), but:

I. Make subject entries under geographic names for such things as trade, sports, churches and religion, transportation, education, music, literature, etc. etc., so far as they directly apply to one region.

2. Analyse all biographies under at least one subject, often two.

3. To save money (only), eliminate detailed collation.

4. Create division, "Early works to [I80o] for social as well as natural sciences."

In this connection, the article by N. P. Barksdale, "Faculty Cooperation with the Library Staff,"1 among other methods sug-

1 Journal of Higher Education 13:146-49, March 1942. 
gests that members of instructional staff collaborate regularly and continuously with the library catalogers in the selection and revision of subject headings, classification, and the like.

Andrew D. Osborn's method of cataloging his college library would be:

I. Put the files of books for reserved reading in a visible index and classify them for that collection. Otherwise let the [reserved] books go uncataloged.

2. Follow circulation needs more closely, e.g., by keeping many variant editions as copies.

3. Keep centralized order and catalog cards for the departmental libraries but do their cataloging as simply and naturally as they now do.

4. Catalog less valuable books more economically. Keep books of little value out of the regular classifications. Plan the classifications so that one class could be closed after a certain time and a new class started.

5. Leave very many documents uncataloged.

6. Make more title entries than we have done, likewise more subject references.

7. Omit authority cards in general.

8. Work cooperatively, but not blindly.

\section{Would You Rather Have "Your" Books Together?}

For a real flier, I added one postscript query: "Or would you rather have all 'your' books in one room and have no card catalog?" I deserved the answers I got, but among them are some good thoughts.

Among the obvious answers were: "Impossible under many conditions and undesirable under all conditions...." "Would make library almost useless. . . ." "Not much. ..." "Impossible. ..." "Yes, but not practical. ..." "Quite acceptable to me...." "What do you mean-'yours'?" "No, we'd be in an awful jam. ..." "Chaotic-heavy loss of books. ..." "A selfish desire. ..." "Very definitely not. ..." "Possible only with whole culture periods" (he knew what I had in mind).

Here are several of the more meaningful answers:

I like the plan of having books widely needed for a course segregated temporarily where students can get at them with a minimum of trouble and where students can easily perceive the large nature and scope of the authorities or sources. (Note: That does not mean to "put them on reserve.")

Heavens, no! I want range. I'd want books from "other" fields continually.

No, but would keep them in the same place. There is too much shifting from section to section. Students complain that when they have learned location in stacks, the books are all changed around the next time they come to the shelves.

Theoretically, but fear there is too much overlapping territory between "my" territory and "yours."

Not when dealing with collections the size of ours, but I do believe in a wise decentralization which can exploit the methods of the special library.

I would arrange a library by major schools or departments-small, easily available. The old library at Pomona or Amherst or Smith was perfect-for me. The grandest library I have used is the one at Brookings: carefully chosen books, on shelves available to everybody, no librarian, self-charging. But that was a small group of mature students: Well, if we adopted an intelligent system, we would have small groups and perhaps more intelligent students.

\section{In Summary}

I believe the foregoing is a fair cross section of the professorial mind as regards cataloging:

1. He wants a good library, well cataloged on standardized lines.

2. He wants a simple catalog.

3. He wants plenty of subject cards, but apparently not the present sort. 
4. He is inclined to think that students do not get too much help from the present catalogs.

5. He believes in cooperative, centralized cataloging.

6. $\mathrm{He}$ is not particularly concerned about the cost of cataloging, if it is well done.

7. He believes in his library staff.

\section{Some of My Own Thoughts}

I. I believe we should take steps to have our teaching and institutional administrative staffs understand more fully what cataloging involves and what it costs. The legend of "enormous" or "fabulous" costs, which unhappily exists, should be brought to earth. The cost of acquiring a book, even the average cost of the book itself, plus the cost of cataloging (perhaps a total of five dollars), should be brought into comparison with the unit-hour cost of instruction of a student (somewhere round five or six dullars an hour, or one hundred and fifty to two hundred dollars per year).

2. We should make up our minds what the catalog is for. I believe, for the ordinary run-of-the-mill book, the catalog is a finding list, pure and simple. For the unusual (or rare) book, the catalog is also partially a bibliographical tool. We should take steps to streamline the handling and the cataloging of the ordinary book. And we should draw the line somewhere as to what constitutes a book requiring detailed, specialized handling in the acquisition and cataloging departments.

3. I am inclined to think that classification is partly responsible for our cataloging problems. Some evidence of the extent of the problem of classification in the minds of catalogers and classifiers is the analysis by $\mathrm{Mr}$. Tauber, of the University of Chicago libraries, of the topics treated in the first ten volumes of the Catalogers' and Classifiers' Yearbook:2 classification leads the list with eighteen papers, then follow centralization and cooperation, nine, subject headings, nine, history and survey, eight, cataloging procedures, seven, costs, seven, organization and administration, six, tributes (to great catalogers), five, union catalogs, four, arrangement of catalogs, four, handling of special material, four, abstracts of theses (summaries), four, rules, three, and twenty other subjects, twenty-seven.

\footnotetext{
2 Tauber, Maurice F. "Review of Catalogers' and Classifiers' Yearbook." Library Quarterly I2:297300, April 1942.
} 